OPEN ACCESS

Edited by:

Valarie Blue Bird Jernigan, Oklahoma State University Center for Health Sciences, United States

Reviewed by:

Nathan McClintock, Institut national de la recherche scientifique, Canada Kawika Winter University of Hawaii at Manoa, United States

*Correspondence: Leslie Hutchins Lhutchin@berkeley.edu

Specialty section: This article was submitted to Social Movements, Institutions and Governance,

a section of the journal Frontiers in Sustainable Food Systems

Received: 24 March 2021

Accepted: 17 August 2021 Published: 10 September 2021

Citation: Hutchins $L$ and Feldman M (2021) What Do Values Have to Do With It? Resilience of Two Types of Farmers in Hawailit to the COVID-19 Pandemic Front. Sustain. Food Syst. 5:685321. doi: 10.3389/fsufs.2021.685321

\section{What Do Values Have to Do With It?: Resilience of Two Types of Farmers in Hawai'i to the COVID-19 Pandemic}

\author{
Leslie Hutchins $^{1 *}$ and Mackenzie Feldman ${ }^{2}$ \\ 'Department of Environmental Science, Policy and Management, University of California, Berkeley, Berkeley, CA, \\ United States, ${ }^{2}$ Data for Progress, New York, NY, United States
}

A history of agriculture and socio-cultural formation has led to a complex local food system in Hawai'i. Customary agricultural systems built by Kānaka 'Ōiwi (Indigenous Hawaiian) are now rested within a landscape filled with many different crops tended by farmers from a variety of ethnic backgrounds. Value systems dictating farming practices and crop selling decisions differ. In Hawai'i, values of food security or food sovereignty are of particular importance, especially as growing movements seek to increase local production and decrease the state's reliance on imported food in the wake of the COVID-19 pandemic. In this study, we systematically compare two different groups of farmers in Hawai'i and their values related to production and distribution. We then analyze the experiences of these two groups of farmers during the COVID-19 pandemic and their responses to them. The study is based on interviews with 22 Indigenous Kānaka 'Ōiwi (IF) and Non-Indigenous local farmers (LF) from the island of O'ahu. Ninety percent of IF say values associated with both food security and sovereignty drive their production and distribution decisions, while $75 \%$ of LF describe food security as the sole driver. Sixty percent of IF follow a non-profit economic model and emphasize cultural and educational values in their production decisions. LF follow profit-driven models and emphasize the influence the market has in their decisions. Prior to the COVID-19 pandemic, IF sold or donated the bulk of their crops to the local community through farm pickups, while restaurants were the primary buyers of LF crops. During the pandemic, the local community continues to be the primary recipient for IF, and due to the closure of many restaurants, LF have pivoted their sales to the community as well. Farmer interviews are augmented by three interviews with Hawai'i food system experts and relevant literature to suggest multiple pathways state agencies and local organizations could implement to support farmers from different backgrounds through COVID-19 and into the future.

Keywords: food sovereignty, food security, Kanaka Maoli, Hawai'i, COVID-19, food system, resilience, local food

\section{INTRODUCTION}

The relationship between a farmer's values and the use of sustainable practices to foster environmental stewardship is well researched (Sullivan et al., 1996; Mccann et al., 1997; Schoon and Grotenhuis, 2000; Ryan et al., 2003; Lincoln and Ardoin, 2016). However, the role ethnic identity plays in this agricultural stewardship relationship, along with crop distribution decisions, 
has not received as much attention (Alkon and Agyeman, 2011). This topic is especially relevant in Hawai' $i$, where the local food system is influenced by a complex history of land tenure, agriculture, and socio-cultural formation. This history has made values associated with food security and food sovereignty particularly prevalent (Loke and Leung, 2013a; Kent, 2016). The local food system has been stressed by the COVID-19 pandemic. In response to COVID-19 spreading across the United States and the globe, Hawai'i State Governor David Ige issued his first emergency proclamation on March 4th, 2020 (Young, 2021). The first COVID-19 case in Hawai'i was subsequently reported on March 6th. On March 23rd a stay-at-home order was issued by Honolulu mayor Kirk Caldwell closing all businesses, except for those deemed essential. On March 26th a 14-day quarantine for out of state travelers was implemented. Subsequent orders were implemented, expired, and reinstated as case numbers fluctuated throughout summer 2020. These orders allowed various businesses to open at limited capacity. In the face of this shifting political and economic landscape, farmers had to display resilience, shift their operations, and pivot their sales.

Drawing from 25 semi-structured interviews with farmers and food system leaders, this paper explores the values driving crop production and distribution for farmers belonging to two different ethnic groups on the island of O'ahu, Hawai'i: Kānaka 'Ōiwi (IF) and non-Kānaka 'Ōiwi local farmers (LF). In addition, we explore how these groups have responded to the COVID-19 pandemic. Specifically, we ask:

(1) How do sociocultural and economic values, including the desire to strive for community food security and food sovereignty, affect the decisions IF and LF make?

(2) To what extent has the response to the COVID-19 pandemic differed between IF and LF? Has one group shown more resiliency through the pandemic thus far?

Broadly defined resilience is the capacity to continue to achieve goals despite disturbances and shocks (Brown et al., 1987; Heller and Keoleian, 2003). In the context of the food system, define resilience as "ensuring sufficient, appropriate and accessible food to all. By sufficient, we understand sufficient quantity and nutritional quality of food; by appropriate, we include the notions of culturally, technically and nutritionally appropriate food; by accessible, we mean physically and economically accessible." To measure their resilience, we examine: the degree to which a farmer's pre-pandemic farming operations, consumer base, sales shifted; and how well positioned they are to continue operating through the pandemic and into the future.

This article proceeds in four parts. First, we outline the history of agriculture and movement building that has led to an agricultural landscape composed of farmers from many different backgrounds. Second, we present quantitative and qualitative findings demonstrating the ways in which IF and LF interact with subsets of consumers and seek out varied means by which to maintain their farming operations. Third, we argue that certain attributes of each value system provided unique opportunities and obstacles in trying to achieve resiliency through the COVID-19 pandemic. Last, we suggest multiple pathways state agencies and local organizations could implement to support farmers from different backgrounds through COVID and into the future.

\section{STUDY SYSTEM BACKGROUND Historical Foundations of Hawai'i's Food System}

Beginning at their first arrival to the Hawaiian Islands, Kānaka 'Öiwi established expansive systems of food production that ranged from offshore fisheries to mountainous agroforestry systems (Vaughan and Vitousek, 2013; Lincoln and Vitousek, 2017). These systems were embedded in socio-political institutions at the personal (religious, see Kame'eleihiwa, 1992), local (ahupua'a, see), and landscape scale (moku, see Winter et al., 2018). Kānaka 'Ōiwi socio-political institutions relied on cultural frameworks emphasizing familial and spiritual connections to land and crops and an understanding of overall community well-being and health (Goodyear-Ka'ōpua et al., 2014; Winter et al., 2020). The act of eating was spiritual, and great significance was attributed to the cultivation of crops (Kamakau and Barrère, 1992). The crop diversity, multi-tier structure, and use of altitudinal and seasonal shifts in these food production systems coupled with the socio-political institutions enabled high productivity and resiliency (Kagawa and Vitousek, 2012; Lincoln and Ladefoged, 2014; Kurashima et al., 2019). For example, Kurashima et al. (2019) concluded that terrestrial cropping systems could have sustained a population of 1.2 million people.

The actions of missionaries, their descendants, and the United States government have had a far-reaching impact on Kānaka 'Ōiwi society. With the first arrival of foreign traders in 1778 and missionaries in 1820, came disease and population decline. Along with a diminished population came shifts in socio-economic, cultural, and religious institutions. To further their religious agenda, missionaries pressured local chiefs to dismantle the customary Kānaka 'Ōiwi spiritual system. Soon many Kānaka 'Ōiwi were enveloped in an entirely new religious system, Christianity, that was not rooted in relationships with the community, land, ali'i and akua (gods). Missionaries exploited their new power and Kānaka 'Ōiwi were coerced into becoming the primary labor force, producing resources for growing settler colonialism on the island of O'ahu, which often came at the expense of their own daily food needs (Steele, 2015).

The 1848 Māhele, a property right and land redistribution act, further affected Kānaka 'Ōiwi land tenure and subsequently food production. Land that had been held in common by communities and produced abundant food was commodified and divided into parcels to be managed on an individual level. Not accustomed to Western land ownership practices, many Kānaka 'Ōiwi did not file claims to any parcel of land (Kame'eleihiwa, 1992). Western businessmen soon bought up and controlled large swaths of the island.

The illegal overthrow of the Kānaka 'Ōiwi Kingdom in 1893 by American businessmen backed by the United States Navy furthered the loss of Kānaka 'Ōiwi food production systems and 
knowledge. The foreign businessmen established a government that suppressed Kānaka 'Ōiwi cultural practices, access to land, and the use of 'olelo Hawai'i (Kānaka 'Ōiwi language) in public and at home (Warschauer et al., 1997). Kānaka 'Ōiwi food production systems and cultivation practices faded with the diminishment of cultural transmission and land access. Moreover, the Kānaka 'Ōiwi worldview and diet shifted under the pressures of colonialism (McMullin, 2016; Silva and Ngugiwa, 2017).

Eurocentric notions of environmental management took hold as well. Government regulation and bureaucracy has also limited the ability of Kānaka 'Ōiwi communities to regain formal management and oversight of traditional food producing regions (Vaughan et al., 2017). Finally, many famous historical native food producing landscapes have been paved over to make way for single family homes, shopping centers, and military bases, or are used for the seed corn industry (Gupta, 2015; Fujikane, 2021).

The result of this history of land and cultural loss has led to a sharp decline in self-sufficiency with Hawai' $\mathrm{i}$ importing almost $90 \%$ of its food. The Kānaka 'Ōiwi population in comparison to the rest of the Hawaiian state has a higher prevalence of hypertension, heart disease, diabetes, and obesity (McMullin, 2016). In addition, a disproportionate number of the Kānaka 'Öiwi population is enrolled in the SNAP benefits program (U.S. Department of Agriculture, Food and Nutrition Service, Office of Policy Support, 2019) and experience a higher poverty rate (13.5) than the averages in the state (9.5).

Seeking to capitalize on a booming need for sugar in the US, and with ample land resources, foreign businessmen established sugarcane plantations in 1835 and imported workers as cheap labor from countries around the world: China, Japan, Philippines, Korea, Portugal, and Germany. These workers brought seeds of new crops as well as cultural traditions with them. While living on plantations, workers exchanged food, recipes, and traditions, ultimately giving rise to what is now known as local food and culture in Hawai'i (Yamashita, 2019). As the sugar industry shifted to South America and the Hawaiian plantations closed, these workers began farming their own plots across the state with polyculture cultivation including rice, taro, and pig (Takaki, 1984).

\section{Movement Building and Food System Transformation in Hawai' $i$}

The birth of the Kānaka 'Ōiwi sovereignty movement is built on the struggles of Kānaka 'Ōiwi farmers and community members who sought to maintain access to their lands and farming practices (Trask, 1987). A group of Kānaka 'Ōiwi farmers and community members facing eviction from their agricultural lands changed the narrative in 1969 by occupying Kalama Valley. Although the subdivision was ultimately built, the stand the Kalama Valley farmers took ushered in a wave of Kānaka 'Ōiwi activism and cultural resurgence that continues to this day. Therefore, the roots of the Kānaka 'Ōiwi sovereignty movement are firmly planted in land access and agriculture but evolved to include cultural revitalization in forms such as language, hula, and ocean wayfinding.
The movement has also evolved to center Kānaka 'Ōiwi conceptualizations of sovereignty and land-based relationships characterized by the terms "ea" and "aloha 'äina." Like most Kānaka "Ōiwi words ea holds multiple meanings including "life," "breath," and "sovereignty." Ea is described as "an active state of being . . . that requires constant action day after day, generation after generation ... [It] is based on the experiences of people on the land, relationships forged through the process of remembering and caring for wahi pana, storied places" (Goodyear-Ka'ōpua et al., 2014). Ea is therefore an understanding that sovereignty and life itself is rooted in caring for and maintaining a relationship with the land. Aloha 'āina encapsulates maintaining a righteous relationship between people and place. It has also become the name and rallying cry of the Kānaka ‘Ōiwi sovereignty movement itself (Osorio, 2002).

Kānaka 'Ōiwi political scientist Noelani Goodyear-Ka'ōopua describes a plurality of sub movements in Hawai' $i$ that contribute to the goals, mainly political and economic autonomy and self-determination, of the broader Kānaka 'Ōiwi sovereignty movement (Goodyear-Ka'ōpua et al., 2014). In this way, the Kānaka 'Ōiwi food sovereignty movement can be seen as a sub movement working towards Kānaka 'Ōiwi sovereignty at large. The first formal mention of this movement can be traced back to Ma'o Farm's "Hands Turned to the Soil" youth conference in 2003 (Meyer, 2014). From that conference came the proliferation of urban gardens and the rise of youth programs centered around cultural and agricultural education. A second food sovereignty conference on Hawai'i Island in 2007 began to define Kānaka 'Ōiwi food sovereignty as "a spiritual, physical and cognitive pathway toward greater wellbeing and self-sufficiency" (Gupta, 2015). A third conference took place in 2018 where a youth congress, comprised of Kānaka 'Ōiwi youth, crafted a future vision for Hawai'i's food system and expanded the definition of Kānaka 'Ōiwi food sovereignty to include the right and responsibility to 'ai pono (righteous food); co-design educational models outside of the classroom; the conscious care of resources for future generations; and uplifting of the community. ${ }^{1}$

The values associated with the Kānaka 'Ōiwi food sovereignty movement are aligned with food sovereignty and Indigenous food sovereignty struggles across the globe. The term food sovereignty was first coined by La Via Campesina in 1996. A commonly cited definition of food sovereignty comes from the Declaration of Nyeleni, where it is defined as "the right of peoples to healthy and culturally appropriate food produced through ecologically sound and sustainable methods, and their right to define their own food and agriculture systems" (Fairbairn, 2010).

A growing body of work from Indigenous scholars across North America have begun to define Indigenous food sovereignty (see Mihesuah et al., 2019; Settee et al., 2020). Moreover, Indigenous food sovereignty is seen as continuation of anticolonial struggles and advancement of self-determination (Grey and Patel, 2015). In this study, we draw on Kānaka 'Ōiwi, Indigenous, and the Declaration of Nyeleni definitions of food sovereignty to define food sovereignty as the right of Kānaka 'Ōiwi to culturally significant foods produced through

\footnotetext{
$\overline{{ }^{1} \text { http://www.youthfoodsovereignty.com/saea-conference.html }}$
} 
ecologically sound methods; manage and access cultural food producing regions; and define their future outside of the purview of the State of Hawai' $i$ and U.S. federal government.

The food landscape in Hawai' $i$ is heavily influenced by a regional food movement started in 1991 by a group of local chefs wanting to utilize locally grown ingredients (Yamashita, 2019). The chefs pushed against a Euro-American food hierarchy stemming from plantation owning families and their descendants who looked down on local food (Laudan, 1996). Influenced by a burgeoning local food movement on the Continental United States and realization that comparable or even better food could be produced in Hawaiian Islands, these chefs began to procure food from local farmers and encouraged them to ramp up production. Since 1991, Hawai'i has seen an exponential rise in marketing schemes and labeling efforts for locally grown food, more farm to table restaurants, and a consumer base that demands locally grown food (Loke and Leung, 2013b).

The regional food movement is heavily aligned with the values of food security and subsequently self-sufficiency. At the heart is also a recognition that importing 90\% of the island chain's food needs is unsustainable and provides little security should a natural disaster arrive. The State of Hawai'i government and other local entities utilize the United Nations Food and Agriculture Organization definition of food security, "a situation that exists when all people, at all times, have physical, social and economic access to sufficient, safe, and nutritious food that meets their dietary needs and food preferences for an active and healthy life" (FAO, 2001). This is the definition of food security utilized in this study as well.

Who are Hawai'i's farmers? Farmer demographic trends mirror the historical shifts discussed previously. The count of Kānaka 'Ōiwi or Pacific Islander farmers declined by half from $22 \%$ in 1900 to $11 \%$ in 1959 . Conversely, in 1900, Hawai'i's principal farmers were of Asian (56\%) and White decent (22\%). In 2012, the number of Kānaka 'Ōiwi or Pacific Islander farmers declined even further to $9 \%$ while Asian and White farmers held large margins at 45 and $43 \%$ respectively (Hollyer and Loke, 2014). The number of farm operators in Hawai' $i$ increased from 2,273 in 1900 to 7,013 in 2012. An overwhelming majority of farms on O'ahu are small scale tending to plots between 1-9 acres $(76 \%)$ or $10-49(15 \%)^{2}$.

\section{METHODS}

Both authors are of Kānaka 'Ōiwi descent and a part of the food system community on the island of O'ahu. Leslie Hutchins first became involved in the local food system while interning with Paepae o He'eia, a local non-profit organization restoring $\mathrm{He}^{\text {'eia }}$ fishpond. Mackenzie Feldman entered the food system through working with local organizations on food system related policy. The conceptualization of this work was born out of numerous informal conversations with farmers of many different backgrounds prior to and during the COVID-19 pandemic. Combined purposive and network sampling approaches to identify and contact potential farmers

$\overline{{ }^{2} \text { https://farmlandinfo.org/statistics/hawaii-statistics/ }}$ was implemented (Blaikie, 2000). In all, 22 interviews using a structured questionnaire approach with farmers across the island of O'ahu were conducted during the summer and fall of 2020 (see Table 1). The ethnic demographic of the farmers included 10 Indigenous Kānaka 'Ōiwi (IF) and 12 non-Indigenous local farmers (LF) comprised of 58\% Asian and $42 \%$ White respondents. Three additional interviews were conducted with food experts and community leaders to help contextualize the interviews and relevant food movement(s). All interviews were conducted over the phone or through online video conference services and recorded for transcription. We used Nvivo 11 to identify common themes within responses. Interview text included in the article is left in its original format to allow the usage of Hawaiian Pidgin (creole langugage spoken in Hawai'i) spoken by several respondents. The "bipartite" package in $\mathrm{R}$ (version 3.6.2) was used to illustrate crop distribution between farmers and consumers. A review of popular, policy, and academic literature along with suggestions from farmers was utilized to write policy recommendations.

\section{RESULTS}

\section{Reasons to Start and Continue Farming}

Although similar reasons for farming were found in both groups, there were clear differences between the two groups in the value placed on Kānaka 'Ōiwi culture and people. When asked whether food security or food sovereignty influenced their decision to start and continue farming, 9 out of 12 LF selected food security while 9 out of 10 IF selected both (Figure 1). Farmers from both LF and IF groups described environmental considerations such as sustainability and climate change as important in their decision to farm. Each farmer had specific reasons for starting their respective farm. However, the reasoning given by LF and IF tended to cluster with their respective group. For example, 6 out of 10 interviewed IF are a part of, or lead, non-profit organizations with in-depth mission statements and goals that seek to increase the socio-economic outcomes for the communities they serve. For example, respondent 11 stated their mission is to provide "a gathering place for people in the community to connect with and care for the 'aina (land), perpetuate Kānaka 'Ōiwi culture through the cultivation and preparation of kalo (taro, Colocasia esculenta), and to be a place that would ultimately bring healing to people, especially at-risk youth."

The remainder of IF suggested similar socio-economic and cultural reasons for starting to farm. Respondent 1 noted how farming kalo became a way to heal from intergenerational trauma associated with growing up surrounded by drug, alcohol, and domestic abuse. They describe working with taro as therapy: "each time my feet step into the mud, it reconnects me to my culture and myself." IF take tremendous pride in growing culturally significant crops such as taro. Respondent 13 described this best saying "our ancestors took great pride in growing the best taro. They'd want to grow the best taro to feed their children and make their keiki [children] warriors. I grow with that same pride. I want my keiki to be strong." However, IF do not solely grow culturally significant crops, 
TABLE 1 | Demographic attributes of interviewed farmers (respondents).

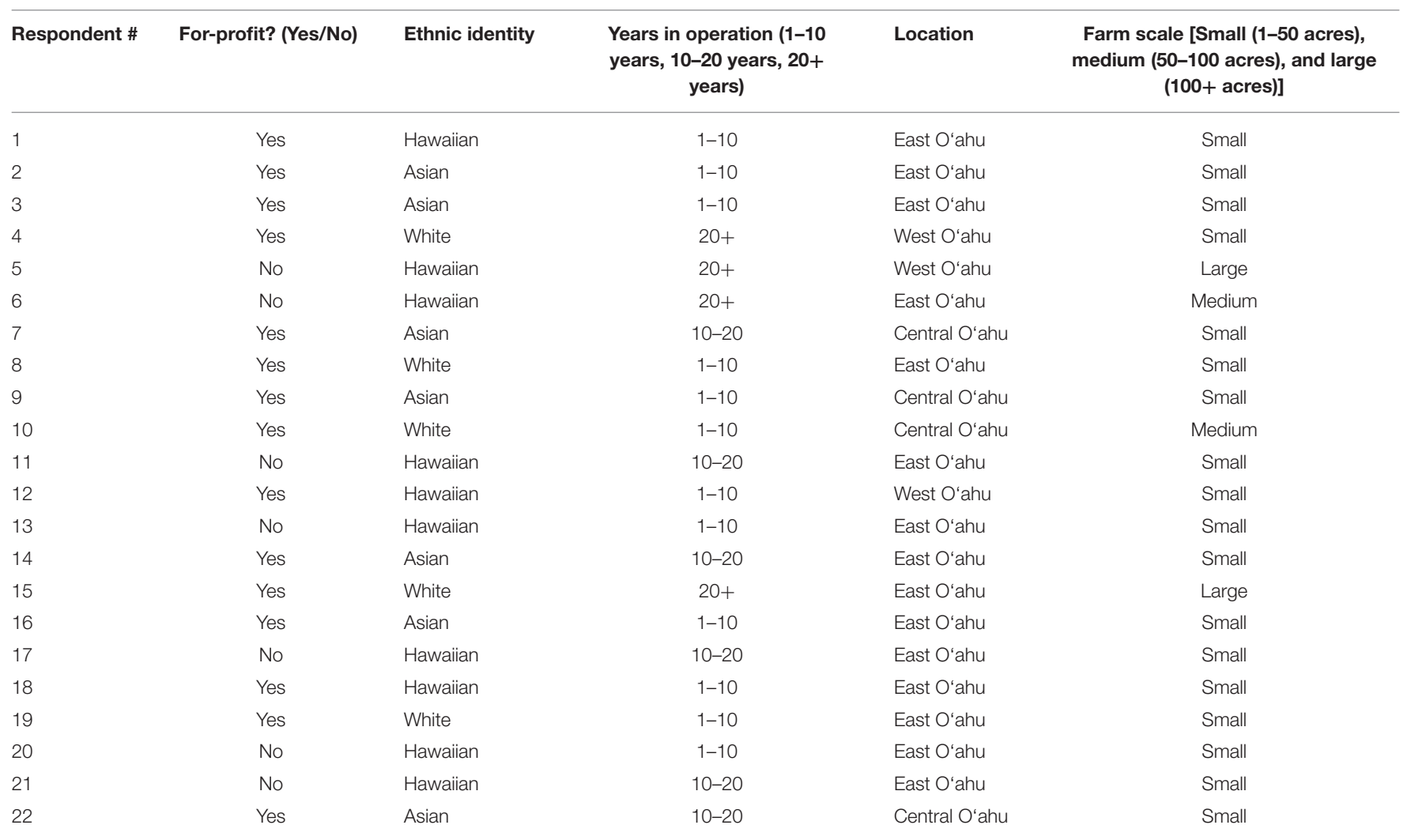

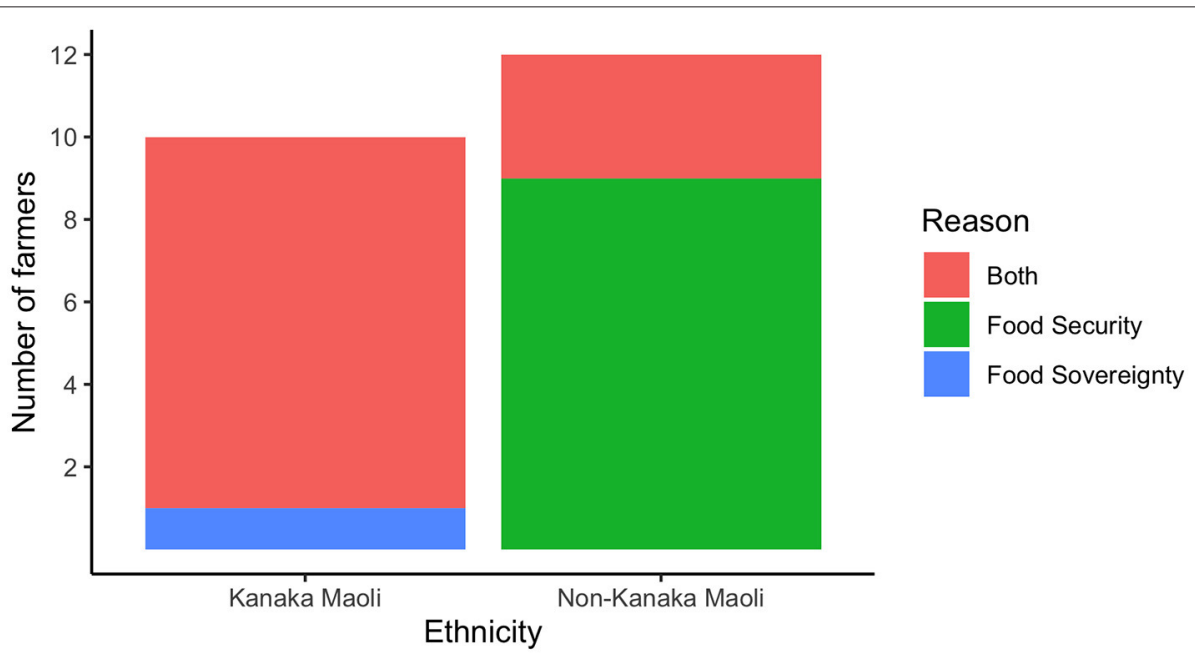

FIGURE 1 | Number of respondents who selected food secuirty, food sovereignty, or both as a reason they began and continue farming.

but also grow to fulfill market demands and cater to new preferences. Respondent 5 noted how they grow not only taro, turmeric (Curcuma longa), sweet potatoes (Ipomea batatas), and other Kānaka 'Ōiwi crops, but kale (Brassica oleracea), arugula (Eruca vesicaria), and many others because "if our Hawaiian ancestors knew about arugula, I'm pretty sure they'd grow it too."
The market is a huge factor in determining what 8 out of $10 \mathrm{IF}$ and 9 out of 12 of LF decide to grow. Respondent 7 described how they grow different crops to cater specifically towards different community demographics represented in the farmers markets they serve: "the Waipahu market has lots of Filipino people, so I'll grow bitter melon and bring it to them. I cater towards Americans at the Kapi'olani Community College and Mililani 
markets, so I grow stuff for salad like kale and lettuce." Other farmers discuss tracking what sells best at their markets and shifting their growing practices accordingly. The 2 out of 10 IF and 5 out of $12 \mathrm{LF}$ with grocery stores discussed the need to focus on high demand and specialty crops. Moreover, they emphasized the need to produce a consistent ample supply to provide to produce managers to keep those accounts open. Respondent 5 explained the crops provided in general are seen as an addition to the supply shipped in from outside the state as opposed to a direct substitution.

\section{Food Sovereignty}

IF see food production as a medium through which larger visions of social and political change can be achieved. Respondent 20 highlighted this saying "what we're doing-it's not only about food; it's not only about kale. We're trying to connect people to place. The food is just a byproduct of trying to get people to connect to "āina (land)."

\section{Access and Kaiāulu (Community)}

Cultivating food provides a way for IF and community members to get their feet in the soil again and an opportunity for Kānaka 'Öiwi crops to spread their roots once more. Eight out of ten interviewed IF host community workdays and cultural activities on their farms, where participants can harvest kalo, learn how to prepare traditional foods, and engage in various ceremonies. Their farms become key gathering places where Kānaka 'Ōiwi community members get to connect and reconnect with others. Moreover, 3 out of 10 IF highlighted how community members often interact with and eat Kānaka 'Ōiwi crops for the first time while visiting.

Many of these organizations are nested within landscapes dominated by other uses-urban, large scale agribusiness, private access-not conducive for many cultural practices. Therefore, their farms can be considered cultural kipuka (safe, regenerative places to be Kānaka 'Ōiwi). Many of their farms feed the community both spiritually and physically by growing and distributing Kānaka 'Ōiwi culturally significant, nutritious crops and engaging in cultural practices they might not be able to access otherwise. Respondent 17 solely started offering educational programs to the community because they noticed a lack of resources about how to grow and prepare Kānaka 'Ōiwi culturally significant crops. In addition, they sell culturally significant crops at a discounted price. They noted that many individuals can only gain access to their ancestral foods because of their programs.

\section{Identity and Place}

Food and the landscape it's grown in are intertwined into the identity of the people belonging to that place. Respondent 5 captured this relationship well: "there's a story behind all food and a lot of indigenous people are tied to that. It's embedded in our culture and our DNA. Food is not only something that gives you life. Food is the resilience of our people, our knowledge, and our ancestor's actions."

Community members participating in workdays are often reminded of the rich history of the landscape and its identity. For example, respondent 11 teaches community volunteers that their ahupua'a (socioeconomic subdivision of land) was once a famous "taro breadbasket" that provided abundance for the entire region. Respondent 6 said they share similar sentiments with volunteers about the fish grown in their fishpond: "Pauahi [a revered Kānaka 'Oiwi ali'i] called the mullet of our fishpond the sweetest mullet she ever tasted, and I would take her word for it more than mine, 'cause she's probably ate way more mullet than me in her lifetime than how much I've eaten. . . the water quality and limu [seaweed] specific to our pond is probably behind the sweetness." Therefore, reclaiming Kānaka 'Ōiwi cultural identity is rooted in revitalizing the cultural landscapes across O'ahu and ensuring their health and abundance. As Respondent 12 puts it "if we have a healthy ahupua'a, we have a healthy community. It takes conscious everyday actions by us and those in the community to restore the abundance of our island home."

\section{Education}

The non-profit model of IF makes education a cornerstone of their operations. By providing hands-on education with a focus on community and culture, IF hope to inspire youth to learn more about themselves and how they can uplift others. Respondent 6 described the goal of their efforts:

"The fishpond feeds us spiritually and educationally. Our job is to try to spark interest in the kids that visit. And, we do. Sometimes those kids that come here and just don't wanna step in the mud, by the end of the day, they do catch on to something. Maybe they're gonna see a fishpond in their community, and they'll be like, "we can do this. We can start somewhere. We can start building this pond." Soon enough, that pond will be feeding people. And then another pond, and then another pond, and that's how we're gonna change communities."

Education is vital to ensuring that the next generation is prepared for a successful future. Using Kānaka 'Ōiwi crops and farming practices as a model, IF offer a robust set of internship programs and funding pathways for personal and professional development. For example, respondent 11's organization offers programs for youth between ages 12 and 23. Their entry level program focuses on improving social functioning and cultural connection for at-risk youth through taro farming and mentorship from life coaches. Their advanced programs offer paid internships and apprenticeships for those in high school and college to gain value-based job preparedness.

\section{Self Determination}

Kānaka 'Ōiwi food sovereignty leads to overall Kānaka 'Ōiwi selfdetermination and sovereignty. Respondent 20 noted how their individual actions contribute to the greater community, "it's all about aloha 'āina. If we can do our own part for our community and teach people about our stories, about haloa as our older brother, and build connection, then hopefully the end result is self-determination." Respondent 13 described food sovereignty and self- determination being achieved through daily actions to grow, gather, and eat traditional Kānaka ‘Ōiwi foods: “you can’t fight for sovereignty by waving a hae Hawai'i [Kānaka 'Ōiwi flag] just 1 day. You have to take action all 7 days. True sovereignty is gained each time a kanaka plants taro. Each time they plant taro, they're planting a hae Hawai'i." 


\section{LF on Food Sovereignty: From Allyship to "Sounds Nice"}

Three out of tweleve LF respondents mentioned food sovereignty inspired their farming operations. Two out of the three see themselves as allys to Kānaka 'Ōiwi food sovereignty. For e.g., respondent 4 leads an innovative extension program from their farm that buys excess harvested fruit (e.g., mangoes and breadfruit) from primarily low-income Kānaka 'Ōiwi households in the surrounding community and sells it at a discounted rate to those in the community. The program provides a secondary source of income for these Kānaka 'Ōiwi households while providing access to crops others across the island could not afford. In this way, although the farm is not operated by nor solely focused on Kānaka 'Ōiwi, respondent 4 described the programs work specifically as being rooted in some Kānaka 'Ōiwi values: "we're creating great abundance, abundance was always here. And I think it's rooted in culture. And I think it's also cultural that people don't want to waste food and that's partially why they want to share food. So our program wanted to become an extension of sharing."

When LF were asked to expand on their reasoning for not engaging in food sovereingty, their responses clustered around having no general knowledge or interest to not wanting to engage in politics. For example, respondent 15 described their lack of knowledge of food sovereignty saying "it sounds nice. Never heard of it. I grow Polynesian crops but I ain't Hawaiian or participate in the sovereignty movement." In terms of the political aspect of food sovereignty, respondent 19 explained " $[$ I'm] just looking to do the farming, not trying to get involved in any politics. I think digging my hands in the soil is an escape for me. It's like an escape from the headlines and what not.

\section{Food Security and Its Interaction With Food Sovereignty}

A majority of LF picked food security as being a primary inspiration for farming. They see their work as a means to provide consistent access to healthy foods to the local community at all times. Respondent 14 encapsulated these sentiments: "I want everyone to have access to healthy food. If the container ships stop coming in, I'll be here to provide."

\section{Community}

Supporting local communities by feeding them is important to LF. Their focus on community is not primarily on Kānaka 'Ōiwi, but those on the island in general and in their specific town. Respondent 2 expressed their joy in feeding the community: "I love going to the farmers markets and seeing community members come by my stall. I'm doing what I am doing for them." 9 out of 12 interviewed LF do not host community workdays or conduct cultural activities on their farms. Respondent 22 gave one possible reason why this might be the case: "hosting requires a lot of organizing and coordinating that I don't have time for. I don't know how the liability and insurance works either. Maybe I'd do it in the future though."

Respondent 4 explained the main driver behind their work with the community is the realization that the food security model emphasized by many in Hawai'i does not seek out justice for all: "with food security, we're actually not even looking at that injustice of who is excluded from the marketplace. . some food security advocates say we should bring food over here as cheaply as possible so that people can afford it and have it but then you're ignoring a lot of people's diets."

In terms of IF, respondent 18 highlighted food security is a matter of empowering a community where many do not have access to healthy food: "a lot of people in the community are stuck going to McDonalds and other fast-food places because that's what they can afford. People in my 'ohana [family] like most families here have a history with diabetes and other stuff like heart disease. I want to give them fresh and healthy food. The homeless kanaka on the beach, they need food now. They need that security.

\section{Past, Present and Future Disaster}

Both LF and IF brought up the importance of being prepared for disastrous situations citing past instances of hurricanes, tsunamis, and the current pandemic as key indicators of why Hawai'i should increase its self-sufficiency and grow more of its own food. Respondent 15 (LF) recalled past and present anxieties to localize the food system: "after the tsunami in 2011, everyone started realizing we need to grow more food here. Everyone was worried about the ports getting destroyed. This pandemic is another good example to show how we need to grow more local. The grocery shelves are getting emptied out. Where are people supposed to turn when Costco no more supplies?"

Ensuring the island is prepared for the future disasters was discussed by $45 \%$ of IF and LF. Respondent 6 (IF) described the virtues of farming in ensuring food security: "The great disaster of Hawai'i is its 7 days of food supply. If the disaster comes, we get 7 days of food. If you can farm, those 7 days don't apply to you. That's out the window. You've got a lifetime supply of food to feed you and your community."

\section{The Taste and Feel of Local Food}

A common sentiment shared by LF revolved around valuing the taste of locally grown food and the pride emmitnating from growing local food. Respondent 8 explained how they favor the taste of local food over imported food: "I always try to eat my own vegetables or the stuff my friends grow. The climate and soil here just makes everything taste better. When I need to eat stuff shipped over from California, I ain't happy. It tastes old.” Respondent 19 described how growing and eating local food makes them feel like a better citizen: "I'm doing part to help the island. Feels good. My customers tell me they feel good buying my products too. They like support too."

The sentiments that local food tastes better and makes you feel better are used by LF to attract customers and potential vendors. These sentiments are shared through in-person conversations, the labeling of products, and advertisement. Respondent 9 explained an interaction they had with a new potential restaurant customer: "We market ourselves as fresh, never frozen. Most people eat frozen chicken imported from the mainland. But fresh chicken is so much better. We made a connection with a restaurant. Told them we had local chicken. They seemed skeptical at first, but then we sent a sample chicken, and they were 
hooked. At first they ordered infrequently, but now they ask for chickens every week."

\section{Two Different Solutions to the Same Problem?}

Food security and food sovereignty are different food system models that LF and IF find themselves participating in. However, there are instances where these two disparate approaches intersect with each other, but only to a certain extent before widely diverging. Although 9 out of $12 \mathrm{LF}$ did not see their work inspired by food sovereignty, their responses nonetheless mirror food sovereignty discourse: LF want to control local food production by increasing production, and do not want to rely so heavily on importing food, which is a main tenet of food sovereignty. Their desire to control the food system, however, is less political than IF and their focus is generally not on culturally significant crops. In addition, LF see working with the State of Hawai $i$, whose food security model relates to economics and individual buying power, to create incremental change, as the primary pathway towards a more localized food system.

IF are part of a community in which many members experience food insecurity, not even gaining daily access to basic nutritious foods. Therefore, they selected food security as a model that would serve them. They focus on both short and longterm ways to feed their communities. In the short-term, IF want to guarantee continued access to healthy food to community members. However, in the long-term, IF seek to dismantle the current food system. In its place, IF want to have the power to create a new system that centers on their cultural values and teachings to determine the future of their community and food system outside the purview of the state.

\section{Adaptations and Pivots During COVID-19 Pre-COVID-19 Production and Marketing Strategies}

Prior to the COVID-19 pandemic, LF and IF experienced a broad range of economic realities. 4 out of 12 LF and 3 out of $10 \mathrm{IF}$ experienced a plateau in sales due to their inability to increase production due to labor or land shortages, while 5 out of $12 \mathrm{LF}$ and 2 out of 10 IF experienced exponential growth with an expansion into hotels and supermarkets. LF and IF often pursued different economic avenues to make ends meet. Due to the non-profit nature of a majority of IF, they commonly seek out external grant funding from local and federal agencies/organizations. Respondent 20, who leads a non-profit, described how they feel like a "subsidized farmer" because their organization does not rely on crop production revenue but grant sources to stay afloat. IF nonprofits rely heavily on a funding model rooted in providing educational services to the community by hosting school groups and/or local companies. Therefore, the non-profit model allows for a suite of outcomes that transcend crop production, including community upliftment. The nonprofit business model also allows IF to conduct the business practices most suitable to their cultural values and communityoriented goals. Respondent 13 expressed this sentiment best: "if I were to run a business, I'd be charging $\$ 7.50$ a pound for taro. Who can afford taro at $\$ 7.50$ a pound? Nobody in my community." On the other hand, grant funding sources in most instances need to be reapplied to every year and provides uncertainty. This uncertainty can make long range planning and staffing difficult. In addition, when applying for funding, IF are faced with rehashing the same precarious solemn narrative about their community. Respondent 17 explained their uneasiness with this narrative: "We're trying to uplift our community. And we've made great strides in doing that, but each grant cycle, I need to talk about the poverty, the diabetes, and the dissarray. I want to start telling new stories."

Taro and poi, the primary staple food of Kānaka 'Ōiwi culture made of steamed and mashed taro, are at the center of 6 out of $10 \mathrm{IF}$ operations. Therefore, the price of these products heavily influences the stability and longevity of IF. For-profit IF may have trouble when selling to the same consumers targeted by nonprofit IF. Respondent 1 described their personal struggle: "the non-profits [are] doing great work, but it can be hard to sell my poi with so many competitors, especially since they have all these big grants and volunteers. I'm only here supporting myself with the money in my pocket." Respondents 11 and 13 provided more insight into the forces determining the price of taro and poi explaining that large scale commercial producers from other islands, such as the Hanalei region of Kaua' $i$, use highly intensive practices and cheap labor to produce a surplus that they then sell at an extremely discounted rate $(\sim 70$ cents/lb as opposed to the $\$ 3-5 /$ lb sought by the respondents).

LF expressed similar issues with large scale commercial production as well. Respondent 7 has seen their fellow vendors at the farmers markets they serve selling produce shipped from the US and abroad instead of locally grown food. They further explained that these vendors can sell their produce at a cheaper price point. 10 out of 12 are for-profit and sell their produce at various markets.

Three out of 10 IF and 6 out of 12 LF pursue secondary sources of income by gaining employment in establishments such as restaurants and engaging in ecotourism by leading farm tours. Engagement in these activities mainly contributes to household income and not necessarily maintaining farming operations. Those engaged in these secondary income activities emphasized the importance of these activities in allowing them to continue farming. Although 59\% of IF and LF expressed good economic health trends, profitability and paying down debt were issues brought up. Farmers expressed that although their sales were increasing, they were still only breaking even due to farm costs and paying down existing debt taken on to purchase equipment or land.

\section{Adapting to COVID-19}

Prior to COVID-19, the crops produced by LF went to a wide assortment of consumers (Figure 2), with farmers markets, restaurants, and high-end restaurants being the primary recipients. However, during COVID, LF experienced a contraction in their consumer base and a pivot in where most crops went, with community-based pick-ups and CSA (Community Supported Agriculture) programs becoming a major recipient. Farmers with restaurant accounts experienced a $70-90 \%$ drop in orders. For example, respondent 3 (LF) experienced a retraction of all their restaurant accounts: "All my sales were going to a handful of restaurants in Waikiki. I lost all 

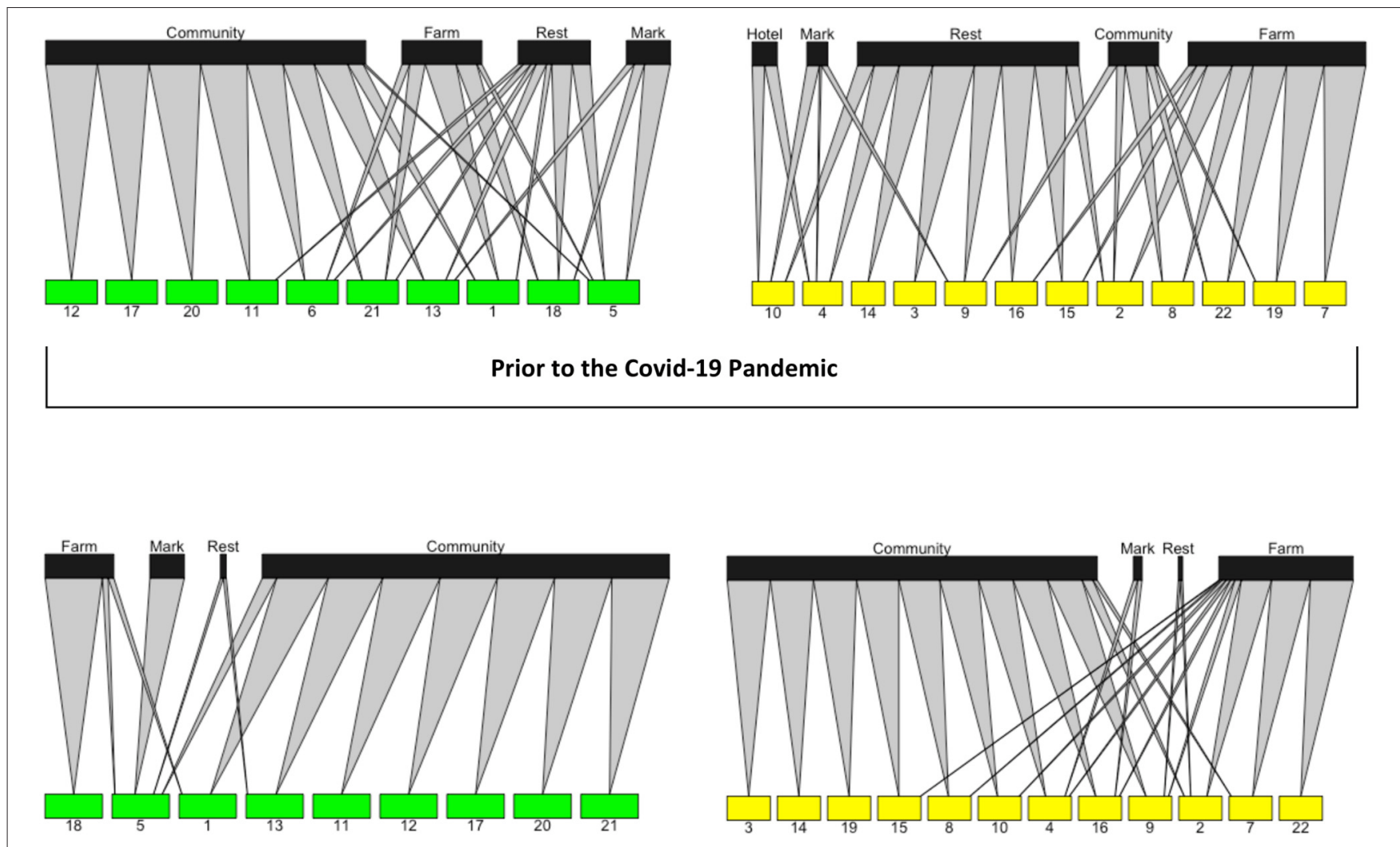

During the Covid-19 Pandemic

FIGURE 2 | The distribution of crop sales between each respondent [lower boxes; green = Kānaka 'Ōiwi Farmers (KF) and yellow = Non-Indigenous Local Farmers (LF)] and different consumer base types [community (e.g. CSA boxes, farm pick ups, and donations), supermarkets (Mark), farmers markets (Farm), restaurants (Rest), and hotels] prior to and during the COVID-19 pandemic. The links between the two represent the proportion of pounds distributed to that consumer base relative to the overall pounds harvested by each respondent.

of those accounts. A couple of CSA services approached me and now I got a bump in sales. I don't know how long it'll last."

Crops produced by IF went overwhelmingly to communitybased pick-ups, with farmers markets and restaurants also being significant recipients (Figure 2). During COVID, communitybased pick-ups and CSA programs became an even more overwhelming recipient of crops receiving the excess associated with the retraction of farmers markets and restaurants. Recipient 22 (LF) described farmers markets remained an important source but many of them temporarily closed: "I go to two farmers markets weekly. The busier market I rely on is temporarily closed. Hope it opens back up soon. I'm harvesting and selling less in the meantime. One market is keeping me afloat for now-barely."

The impacts of the COVID-19 pandemic required almost all farmers to innovate and change their business model. As the local population began to seek out opportunities to avoid in person contact in grocery stores and honor the idea of buying more local, farmers set up online sales platforms, "drive- thru" pick up options, and joined or created their own direct to consumer CSA programs. LF and IF both benefited from the uptick in community sales, seeing a 2-5-fold increase in CSA based subscriptions. However, the drastic increase in demand for CSA services has not been a golden opportunity seized by all. Farmers that do not already have the infrastructure in place or the resources to acquire it may be at a disadvantage. For example, respondent 7 primarily relies on a two-to-fourperson work crew and could not keep up with the demand from CSA services. Since they did not have the capital to pay more workers, they had to stop production for CSA accounts all together.

Respondent 4 (LF) and respondent 17 (IF), both of whom focus on food security and food sovereignty, did not need to change their business model, they instead ramped up their prepandemic strategies. In addition to growing their own crops, they procure crops from other small-scale farms and act as a hub of distribution. Respondent 17 explained how their work has enabled many small-scale farmers to continue operations throughout the pandemic:

"Prior to the pandemic, we were buying from maybe eight farmers, but now we are up to around 15 every week. That has increased our distribution from 500 pounds to 2,000 per week. The farmers are from all over the island. A couple of them 
have said we are solely contributing to their persistence. It feels good to help out but its heavy knowing we are their lifeline at the moment."

The pandemic proved to be troublesome for IF non-profits that rely on volunteer help and received income from education programs as well. As schools and summer programs moved to online platforms and the State of Hawai' $\mathrm{i}$ implemented restrictions on group gathering, income revenue from education sources declined. Moreover, the volunteer help often needed to complete laborious tasks disappeared. IF expressed anxiety in terms of grant money drying up due to the economic crisis, thus either eliminating significant sources of funding or making them even more competitive to receive. Respondent 12 and 21 have started to consider implementing new production-oriented funding models, such as increasing crop acreage and acquiring more land.

Four out of 12 LF and 8 out of 10 IF mentioned interfarm relationships became especially important to gain advice on how to adapt to and sell their crops during the pandemic. For IF, this involved relying on relationships that have been forged and tended to over many years. Prior to the pandemic, inter-farm visits between IF commonly occurred. During these visits, farmers from two or more farms would come together to complete a large task or learn how to care for a unfamilar crop. During the pandemic, these visits shifted towards picking up the extra slack from a lack of volunteer help and perpetuating a sense of community between farmers. For LF, the pandemic provided inspiration to reach out to fellow farmers they had not spoken to years or ever. Their discussions centered on discussing what markets are open, what crops are popular, and how to operate with CSAs in mind. Both IF and LF found avenues within their respective communities or between their communities to make joint value-added products or incorporate each other's products in CSA boxes.

\section{Food Security and Food Sovereignty Resiliency}

Throughout the pandemic, three IF have led large initiatives to give out free taro and sweet potato cuttings to the community. They have done so by organizing drive thru events and community pickups. Each person that shows up receives a handful of cuttings they can take home and grow in their own garden. Respondent 1 discussed the importance of providing cuttings: "This is to create more resilience for our Kānaka 'Ōiwi families out there. They can take the huli [taro cutting] plant them and it'll grow a corm they can eat and keiki [off shoots] they can plant. They can even give the keiki to more 'ohanas so they can grow too. It's like that old saying: Give a man and fish and they can eat for the day. Teach him how to fish and he'll eat forever."

IF have experienced less of a pivot in crop distribution in comparison to LF. The focal recipient of their crops was community both before and during the pandemic. Moreover, the strong value placed on forging relationships with others in the community has proven to be an invaluable source of work aid and crop sales. However, IF with a non-profit funding model are facing some form of financial instability now and into the future. LF experienced a greater pivot in distribution in comparison to IF, as the restaurant accounts they relied greatly on closed abruptly. However, CSA programs have improved their stability through the pandemic. Three LF discussed forming a relationship with food bank programs in the State of Hawai'i during the pandemic. Respondent 23 pointed out the complexities in such a relationship: "The Hawai $i$ Foodbank is doing great work to get food to people. Lots of farmers I work with have been delivering crops to the foodbank. And we all want to continue to help but they want to buy their crops at a pretty discounted rate. I don't know how long they could sustainably give a bulk of produce to them at that price."

The relationships formed between the farmers and food banks, and the formation of the food banks themselves, are centered on food security and localization. Food security on O'ahu has and is currently keeping farmers afloat, but has not exactly enabled them to be resilient and thrive economically. Food security initiatives are essential in providing food to the community, especially during rough times, but it is more of a response to a dysfunctional system than a pathway for long term resilience. IF have deployed food sovereignty strategies and from a standpoint of crop distribution pivoting and relationship strength have shown greater resiliency through the pandemic. As the pandemic continues and as the island moves forward into the future, both IF and LF can work together to overcome challenges, become more resilient, and feed the local and Kānaka 'Ōiwi community at different time scales. Many of the aspirations of IF, and the food sovereignty movement in general, are a long-term undertaking that cannot easily be met in the short term. Food security provides a short-term solution to address some food system problems but does not meet the overall goals of LF and IF in the long term.

Future studies might include a larger respondent size and an inclusion of more for-profit Kānaka 'Ōiwi farmers. As the study went on, we found it increasingly relevant to interview non-profit IF, partially due to the sheer number of them, but also because we found it to be the model most conducive to their values and mission. However, keying in on the struggles of the for-profit IF may illuminate additional or contrasting values to the non-profit IF. In addition, since this study was conducted during the summer of 2020, future work might capture the later impacts of the pandemic on farmers and their recovery.

\section{CONCLUSION: INTEGRATING FINDINGS INTO POLICY}

We conclude with suggestions that state and federal agencies and local organizations could implement to support farmers from different backgrounds through COVID19 and into the future. During discussions with farmers, sentiments of wanting to see change happen through a 
shift in policy was brought up frequently. These policy pathways are centered on increasing food supply chain access; and mitigating financial and bureaucratic barriers. It should be recognized that these policy and broader food system shifts will require a sustained effort by all parties to be realized.

IF are currently seen as essential sources of place-based education for the local community as a whole. However, these sites should also be seen as key producers and suppliers of culturally significant foods. Legislation intended to expand the Hawai'i farm to school program (Act 218, Session Laws of Hawai' i 2015) and meet current goals to source $15 \%$ by 2025 and $30 \%$ by 2030 of public-school meals locally should require a portion of each percentage to be acquired from IF. This would be especially helpful for IF non-profit organizations seeking to diversify their financial portfolio to focus on education and production due to pandemic related hardship. This will allow Kānaka 'Ōiwi children, who represent the single largest ethnic group in Hawai' i public elementary and secondary school student population, to gain access to culturally significant foods they might not otherwise encounter at home (Goodyear-Ka'ōpua, 2013). In addition, the expansion of the program will further uplift the numerous LF that already participate.

Loans and microloans are valuable to farmers looking to invest in new infrastructure, acquire land, implement innovate crop plans, and meet food safety and processing standards. However, eligibility and high interest rates have long been a barrier. Legislation to expand loan programs with increased eligibility and lower interest rates for farmers could prove pivotal to many pivoting and rethinking business plans through and after the pandemic. Likewise, partnerships between State of Hawai $i$, federal, and private partners to expand grant programs and their scope could be especially beneficial (Croix and Mak, 2021). In addition to expanding loan and grant programs, dedicated support and education should be provided to farmers to help them understand what they qualify for and how to complete successful loan and grant applications. Respondent 9 discussed their interest in expanding their business but felt held back because of the grant application process: "I want to venture into the realm of making value added products. The opportunity is there, but I am limited by money and time. I see grants pop up here and there that could be helpful. I don't even know how to go about applying for one-what do I write?"

For IF and the Kānaka 'Ōiwi community, gaining access to ancestral lands to restore cultural food producing regions and increase the abundance of culturally significant foods is a priority. Efforts to restore abundance and gain access to sites have long faced bureaucratic barriers erected by the State. Many cultural food producing regions are zoned for conservation or exhibit a need for more formal community oversight and cultural values to ensure persistence of abundance. Therefore, communities often go through community-based subsistence fishing areas (CBSFAs), Memorandum of Understanding (MOU), or seek administrative rule changes to gain access to an area and engage in co-management. These processes often involve unequal power relations and a disregard for different world views and data types (Ayers et al., 2018). While there have been legislative wins (see
Hobart, 2017; McMillen et al., 2017; Vaughan et al., 2017), the time, effort and adherence to bureaucratic red tape required to achieve those wins has often minimized their scale and efficacy (Vaughan and Caldwell, 2015). Legislation to streamline bureaucratic barriers and designate additional CBSFAs and carry out more MOU sought out by communities should be considered. In addition, amendments to conservation zoning should be done to encourage the efficient use of conservation lands for Kānaka 'Öiwi food production now and into the future. This recommendation, however, represents incremental change within the existing governing structure of the state. The sovereignty movement that many IF and those in the broader Kānaka 'Ōiwi community engage in seeks land restitution and greater political autonomy. Therefore, for the goals of Kānaka 'Ōiwi food sovereignty to be fully realized, state and federal officals must engage in meaningful dialogue with Kānaka 'Ōiwi communities to initate pathways towards land restitution and political sovereignty. Until these actions take place Kānaka 'Ōiwi community members will find themselves in a contentious position in trying to realize feed and empower their communities.

These policy suggestions and the main findings of this study provide academics, policy makers and public servants, community leaders, and food system practioners with an upto-date analysis of a diverse local food system comprised of Indigenous and non-Indigenous community members impacted by COVID-19, along with actionable strategies for achieving resilience and equity for all members of the community. We specifically focused on farmers values associated with food sovereignty and food security, and the degree of resiliency each provides through the COVID-19 pandemic. Both groups of farmers shared similar values when it came their reasoning to begin farming and providing food to the community, but they diverged on their specific focus, intentions, and envisioned futures. IF values are associated with food sovereignty. They are focused on revitalizing their cultural practices and crops while uplifting Kānaka 'Ōiwi communities. IF are utilizing food as pathway towards greater political sovereignty. LF values are associated with food security. They are focused on feeding local communities and are not focused on growing culturally significant crops. LF seek to work with the State to achieve greater food security. LF and IF interacted with different subsets of consumers prior to the COVID-19 pandemic, with the community being the primary recipient of IF crops, and restaurants the main recipient of LF crops. As the impacts of the pandemic took hold, both LF and IF had to adapt and show resilience. IF pivoted less of their crop distribution and relied on established relationships with other IF to adapt. LF pivoted a lot of their crop distrubution from restaurants to community based programs. Both LF and IF face barriers in continuing to operate during the pandemic and into the future. However, both groups have a vision for a better agricultural future that will require consistent participation between themseleves, political representatives, and other related programs and officials. Policies that uplift both groups and their associated values through the pandemic and into the future should be considered. These policies should be centered on food supply chain and land access, 
financial and bureaucratic barriers, and fostering relationships among farmers.

\section{DATA AVAILABILITY STATEMENT}

The raw data supporting the conclusions of this article will be made available by the authors, without undue reservation.

\section{ETHICS STATEMENT}

The studies involving human participants were reviewed and approved by UC Berkeley Committee for Protection of Human Subjects Institutional Review Board. Written informed consent for participation was not required for this study in accordance with the national legislation and the institutional requirements.

\section{AUTHOR CONTRIBUTIONS}

LH conceptualized the study, analyzed the data, and wrote the first draft. Both LH and MF conducted interviews and edited

\section{REFERENCES}

Alkon, A. H., and Agyeman, J. (eds.) (2011). Cultivating Food Justice: Race, Class, and Sustainability. Cambridge, MA: MIT Press. doi: 10.7551/mitpress/8922.001.0001

Ayers, A. L., Kittinger, J. N., and Vaughan, M. B. (2018). Whose right to manage? Distribution of property rights affects equity and power dynamics in comanagement. EandS 23:37. doi: 10.5751/ES-10124-230237

Blaikie, N. W. H. (2000). Designing Social Research: the Logic of Anticipation. Cambridge, UK; Malden, MA: Polity Press.

Brown, B. J., Hanson, M. E., Liverman, D. M., and Merideth, R. W. (1987). Global sustainability: Toward definition. Environ. Manag. 11, 713-719. doi: 10.1007/BF01867238

Croix, S., and Mak, J. (2021). Reviving Agriculture to Diversify Hawaii's Economy. Honolulu: The Economic Research Organization at the University of Hawaii.

Fairbairn, M. (2010). "Framing resistance; international food regimes and the roots of food sovereignty," in Food Sovereignty: Reconnecting Food, Nature and Community (Oakland, CA: Food First Books).

FAO (2001). The State of Food Insecurity in the World 2001. Rome: Food and Agricultural Organization of the United Nations.

Fujikane, C. (2021). Mapping Abundance for a Planetary Future: Kanaka Maoli and Critical Settler Cartographies in Hawai i. Durham: Duke University Press. doi: $10.1215 / 9781478021247$

Goodyear-Ka'ōpua, N. (2013). The Seeds We Planted: Portraits of a Native Hawaiian Charter School. Minneapolis, MI: University of Minnesota Press. doi: 10.5749/minnesota/9780816680474.001.0001

Goodyear-Ka‘ōpua, N., Hussey, I., and Wright, E. K. (eds.) (2014). A Nation Rising: Hawaiian Movements for Life, Land, and Sovereignty. Durham: Duke University Press. doi: 10.1215/9780822376552

Grey, S., and Patel, R. (2015). Food sovereignty as decolonization: some contributions from Indigenous movements to food system and development politics. Agric. Hum Values 32, 431-444. doi: 10.1007/s10460-014-9548-9

Gupta, C. (2015). Return to freedom: Anti-GMO Aloha 'Āina Activism on Molokai as an expression of place-based food sovereignty. Globalizations 12, 529-544. doi: 10.1080/14747731.2014.957586

Heller, M. C., and Keoleian, G. A. (2003). Assessing the sustainability of the US food system: a life cycle perspective. Agric. Syst. 76, 1007-1041. doi: 10.1016/S0308-521X(02)00027-6

Hobart, H. J. (2017). A "Queer-Looking Compound": race, abjection, and the politics of Hawaiian Poi. Glob. Food History 3, 133-149. doi: 10.1080/20549547.2017.1352441 manuscript drafts. All authors contributed to the article and approved the submitted version.

\section{FUNDING}

LH was sponsored by a Berkeley Food Institute graduate student fellowship and a food and agriculture systems graduate fellowship from the Intertribal Agriculture Council (IAC) and The Inter-institutional Network for Food, Agriculture and Sustainability (INFAS).

\section{ACKNOWLEDGMENTS}

We would like to thank Louise Fortmann, Barbara Joan Tiger Bass, Elizabeth Hoover, and the Indigenous Environmental Studies lab at the University of California, Berkeley for helpful comments on manuscript drafts. We would also like to thank Louise Fortmann for her invaluable help, encouragement, and expertise while conducting interviews and framing the scope of the project.

Hollyer, J. R., and Loke, M. K. (2014). Some demographic characteristics of farm operators in Hawai'i: a century of change. Econ. Issues 4.

Kagawa, A. K., and Vitousek, P. M. (2012). The Ahupua'a of Puanui: a resource for understanding hawaiian rain-fed agriculture. Pac. Sci. 66, 161-172. doi: 10.2984/66.2.6

Kamakau, S. M., and Barrère, D. B. (1992). The works of the people of old $=: \mathrm{Na}$ hana a ka po'e kahiko. Repr. d. Ausg. 1976. Honolulu: Bishop Museum Press.

Kame'eleihiwa, L. K. (1992). Native Land and Foreign Desires: How Shall We Live in Harmony? Ko Hawaii Aina a me Na Koi Puumake a ka Poe Haole. Honolulu: Bishop Museum Press.

Kent, G. (2016). "Food security in Hawaii," in Food and power in Hawaii (Honolulu, Hawaii: University of Hawai'i Press), 36-54.

Kurashima, N., Fortini, L., and Ticktin, T. (2019). The potential of indigenous agricultural food production under climate change in Hawai'i. Nat. Sustain. 2, 191-199. doi: 10.1038/s41893-019-0226-1

Laudan, R. (1996). The Food of Paradise: Exploring Hawaii's Culinary Heritage. Honolulu: University of Hawai'i Press.

Lincoln, N., and Ladefoged, T. (2014). Agroecology of pre-contact Hawaiian dryland farming: the spatial extent, yield and social impact of Hawaiian breadfruit groves in Kona, Hawai'i. J. Archaeol. Sci. 49, 192-202. doi: 10.1016/j.jas.2014.05.008

Lincoln, N. K., and Ardoin, N. M. (2016). Cultivating values: environmental values and sense of place as correlates of sustainable agricultural practices. Agric. Hum. Values 33, 389-401. doi: 10.1007/s10460-015-9613-z

Lincoln, N. K., and Vitousek, P. (2017). "Indigenous Polynesian Agriculture in Hawai i," in Oxford Research Encyclopedia of Environmental Science. Oxford: Oxford University Press. doi: 10.1093/acrefore/9780199389414.013.376

Loke, M. K., and Leung, P. (2013a). Competing food concepts-implications for Hawai' i, USA. Food Energy Secur. 2, 174-184. doi: 10.1002/fes3.33

Loke, M. K., and Leung, P. (2013b). Hawai'i's food consumption and supply sources: benchmark estimates and measurement issues. Agric. Econ. 1:10. doi: 10.1186/2193-7532-1-10

Mccann, E., Sullivan, S., Erickson, D., and Young, R. D. (1997). Environmental awareness, economic orientation, and farming practices: a comparison of organic and conventional farmers. Environ. Manag. 21, 747-758. doi: $10.1007 /$ s002679900064

McMillen, H., Ticktin, T., and Springer, H. K. (2017). The future is behind us: traditional ecological knowledge and resilience over time on Hawai'i Island. Reg. Environ. Change 17, 579-592. doi: 10.1007/s10113-016-1032-1

McMullin, J. M. (2016). The Healthy Ancestor: Embodied Inequality and the Revitalization of Native Hawaiian Health. London: Routledge. Available online 
at: https://www.taylorfrancis.com/books/e/9781315418339 (accessed March 23, 2021).

Meyer, M. A. (2014). Hoea Ea: land education and food sovereignty in Hawaii. Environ. Educ. Res. 20, 98-101. doi: 10.1080/13504622.2013.852656

Mihesuah, D. A., Hoover, E., and LaDuke, W. (eds.) (2019). Indigenous Food Sovereignty in the United States: Restoring Cultural Knowledge, Protecting Environments, and Regaining Health. Norman: University of Oklahoma Press.

Osorio, J. K. (2002). Dismembering lāhui: a history of the Hawaiian nation to 1887. Honolulu: University of Hawai'i Press. doi: 10.1515/9780824845407

Ryan, R. L., Erickson, D. L., and De Young, R. (2003). Farmers' motivations for adopting conservation practices along Riparian zones in a midwestern agricultural watershed. J. Environ. Plan. Manag. 46, 19-37. doi: 10.1080/713676702

Schoon, B., and Grotenhuis, R. (2000). Values of farmers, sustainability and agricultural policy. J. Agric. Environ. Ethics 12, 17-27. doi: 10.1023/A:1009543907661

Settee, P., Shukla, S., and ProQuest (Firme) (2020). Indigenous Food Systems: Concepts, Cases, and Conversations. Available online at: https://go.openathens. net/redirector/umoncton.ca?url=https $\% 3 \mathrm{~A} \% 2 \mathrm{~F} \% 2 \mathrm{Febookcentral}$.proquest. com\%2Flib\%2Fumoncton-ebooks\%2Fdetail.action\%3FdocID\%3D6282046 (accessed March 23, 2021).

Silva, N. K., and Ngugiwa, T. (2017). The Power of the Steel-Tipped Pen: Reconstructing Native Hawaiian Intellectual History. Durham, London: Duke University Press. doi: 10.1515/9780822373131

Steele, C. (2015). He Ali'i Ka 'Āina; He Kauwā ke Kanaka (The Land is Chief; Man is its Servant). Traditional Hawaiian Resource Stewardship and the Transformation of the Konohiki.

Sullivan, S., Mccann, E., De Young, R., and Erickson, D. (1996). Farmers' attitudes about farming and the environment: a survey of conventional and organic farmers. J. Agric. Environ. Ethics 9, 123-143. doi: 10.1007/BF03055298

Takaki, R. T. (1984). Pau hana: Plantation Life and Labor in Hawaii, 1835-1920. Honolulu: University of Hawaii Press.

Trask, H. K. (1987). The birth of the modern Hawaiian movement: Kalama Valley, O'ahu. Hawaiian J. History 21, 126-152.

Vaughan, M. B., and Caldwell, M. R. (2015). Hana Pa'a: challenges and lessons for early phases of co-management. Mar. Policy 62, 51-62. doi: 10.1016/j.marpol.2015.07.005

Vaughan, M. B., Thompson, B., and Ayers, A. L. (2017). Pāwehe Ke Kai a'o Hā'ena: creating state law based on Customary Indigenous
Norms of Coastal Management. Soc. Nat. Resourc. 30, 31-46. doi: 10.1080/08941920.2016.1196406

Vaughan, M. B., and Vitousek, P. M. (2013). Mahele: sustaining communities through small-scale inshore fishery catch and sharing networks. Pac. Sci. 67, 329-344. doi: 10.2984/67.3.3

Warschauer, M., Donaghy, K., and Kuamoÿo, H. (1997). Leoki: a powerful voice of Hawaiian language revitalization. Comput. Assist. Lang. Learn. 10, 349-361. doi: 10.1080/0958822970100405

Winter, K., Beamer, K., Vaughan, M., Friedlander, A., Kido, M., Whitehead, A., et al. (2018). The Moku system: managing biocultural resources for abundance within social-ecological regions in Hawai'i. Sustainability 10:3554. doi: 10.3390/su10103554

Winter, K. B., Lincoln, N. K., Berkes, F., Alegado, R. A., Kurashima, N., Frank, K. L., et al. (2020). Ecomimicry in Indigenous resource management: optimizing ecosystem services to achieve resource abundance, with examples from Hawai' i. EandS 25:26. doi: 10.5751/ES-11539-250226

Yamashita, S. H. (2019). Hawai'i Regional Cuisine: the Food Movement That Changed the Way Hawai $i$ eats. Honolulu: University of Hawai'i Press.

Young, C. (2021). A COVID-19 Timeline: How Honolulu Got To This Point. Honolulu Magazine. Available online at: https:/www.honolulumagazine.com/ a-covid-19-timeline-how-honolulu-got-to-this-point/ (accessed March 10, 2021).

Conflict of Interest: The authors declare that the research was conducted in the absence of any commercial or financial relationships that could be construed as a potential conflict of interest.

Publisher's Note: All claims expressed in this article are solely those of the authors and do not necessarily represent those of their affiliated organizations, or those of the publisher, the editors and the reviewers. Any product that may be evaluated in this article, or claim that may be made by its manufacturer, is not guaranteed or endorsed by the publisher.

Copyright (c) 2021 Hutchins and Feldman. This is an open-access article distributed under the terms of the Creative Commons Attribution License (CC BY). The use, distribution or reproduction in other forums is permitted, provided the original author(s) and the copyright owner(s) are credited and that the original publication in this journal is cited, in accordance with accepted academic practice. No use, distribution or reproduction is permitted which does not comply with these terms. 